\title{
Review of the genus Shirleyrhynchus Beveridge \& Campbell, 1988 (Trypanorhyncha: Shirleyrhynchidae), with the resurrection of $S$. butlerae Beveridge \& Campbell, 1988 and the description of $S$. panamensis n. sp.
}

\section{Bjoern C. Schaeffner}

Received: 18 November 2015 / Accepted: 11 March 2016

\author{
B. C. Schaeffner $(\bowtie)$ \\ Instituto de Biociências, Universidade de São Paulo, Rua do Matão, 321 05508-900 Cidade \\ Universitária, São Paulo, SP, Brazil \\ e-mail: b.schaeffner@unimelb.edu.au
}

\begin{abstract}
A new species of trypanorhynch cestode is described from two species of stingrays, the Panamic stingray Urotrygon aspidura (Jordan \& Gilbert) and the Pacific chupare Himantura pacifica (Beebe \& Tee-Van) collected in the Golfo de Montijo in the Eastern Pacific Ocean off the coast of Panama. Shirleyrhynchus panamensis n. sp. represents an important addition to the family, which until now consisted of two monotypic genera. The new species is characterised by an elongate scolex with four, ovate bothria, presence of prebulbar organs, absence of gland cells within the muscular bulbs and an oncotaxy with a typical heteroacanthous, heteromorphous tentacular armature, a characteristic basal armature and the presence of a slight basal swelling. It is readily distinguished from its congeners by a smaller scolex and features of the oncotaxy, such as dissimilar hooks on opposing principle rows, a commencement of hook rows from the bothrial to the antibothrial surface and a much shorter basal armature. Although described only on the basis of immature worms lacking a strobila, the new species adds information on features of the oncotaxy within Shirleyrhynchus Beveridge \& Campbell, 1988. Observation of the holotype of Shirleyrhynchus aetobatidis (Shipley \& Hornell, 1906) revealed apparent differences from Australian specimens that have been described as Shirleyrhynchus butlerae Beveridge \& Campbell, 1988 but which were later synonymised. Observations of type-specimens of S. butlerae also
\end{abstract}


revealed differences from the original description and some morphological characteristics are amended. Shirleyrhynchus butlerae is herein resurrected and an amended generic diagnosis and a key to the identification of species are provided. The molecular voucher specimen of 'S. aetobatidis' utilised in previous molecular phylogenetic studies was re-observed which revealed a misidentification of the specimen with Parachristianella indonesiensis Palm, 2004.

\section{Introduction}

The trypanorhynch genus Shirleyrhynchus Beveridge \& Campbell, 1988 was erected by Beveridge \& Campbell (1988) to accommodate a single species, S. butlerae Beveridge \& Campbell, 1988. The authors assigned the monotypic genus to the Gilquiniidae, entirely based on the presence of four bothria. However, they stated that Shirleyrhynchus also shared morphological features present in other trypanorhynch families. Features of the segment morphology and oncotaxy would have allowed a placement within the Eutetrarhynchidae, such as the arrangement of testes in two longitudinal columns, a median uterus, the presence of prebulbar organs and elongate bulbs. Moreover, some morphological characteristics were similar to the Rhinoptericolidae, such as the number of bothria, uterine diverticula, testes arrangement, the presence of an armed cirrus and preequatorial genital pores. Beveridge \& Campbell (1988) thus raised their concerns about a separation of families based exclusively on the number of bothria. After observing the trypanorhynch collection of A. E. Shipley and J. Hornell at the Naturhistorisches Museum in Vienna, Beveridge \& Campbell (1998) discovered the holotype of Tetrarhynchus aetobatidis Shipley \& Hornell, 1906. This species was described by Shipley \& Hornell (1906) from the spotted eagle ray, Aetobatus narinari (Euphrasen) collected in Sri Lanka (formerly 'Ceylon'). The single immature specimen deposited in Vienna allowed Beveridge \& Campbell (1998) to briefly redescribe $T$. aetobatidis, allocate it into Shirleyrhynchus and synonymise it with the type-species $S$. butlerae as $S$. aetobatidis (Shipley \& Hornell, 1906) Beveridge \& Campbell, 1998. Later, Campbell \& Beveridge (1994) combined Shirleyrhynchus with Cetorhinicola Beveridge \& Campbell, 1988 to form a new

family Shirleyrhynchidae Campbell \& Beveridge, 1994. Palm (2004) placed Shirleyrhynchus within the trypanorhynch superfamily Eutetrarhynchoidea and added a third genus, Rhinoptericola Carvajal \& Campbell, 1975 to the Shirleyrhynchidae. The combination of these genera necessitated a change in the family name and Shirleyrhynchidae became a junior synonym of the Rhinoptericolidae Carvajal \& Campbell, 1975. 
Recent molecular phylogenetic analyses performed by Palm et al. (2009) and Olson et al. (2010) revealed discrepancies in the classification based on morphology. In both analyses, rhinoptericolid representatives were paraphyletic and $S$. 'aetobatidis' grouped with representatives of the Eutetrarhynchidae Guiart, 1927 and Mixodigmatidae Dailey \& Vogelbein, 1928. In 2010, Palm (2010) described another monotypic genus, Nataliella Palm, 2010, within the Rhinoptericolidae and separated the family (including the two monotypic genera Rhinoptericola and Nataliella) from the Shirleyrhynchidae, including Shirleyrhynchus and Cetorhinicola. However, Palm (2010) did not explain his decision for the resurrection of the Shirleyrhynchidae. Morphological characters that unite members of the Shirleyrhynchidae might be unambiguous, such as the presence of four bothria and a heteroacanthous tentacular armature. However, finding explanations for the formation of a phylogenetic clade that incorporates members of the Shirleyrhynchidae, Eutetrarhynchidae and Mixodigmatidae proves complicated (see below).

Observations of the holotype of $S$. aetobatidis and type-specimens of $S$. butlerae revealed novel morphological characteristics of the oncotaxy and many characteristics previously stated in the original descriptions need to be amended. Due to apparent differences in the morphological characteristics and metrical data of the holotype of S. aetobatidis from Sri Lanka and the Australian specimens, S. butlerae is herein resurrected. Moreover, the present study adds a third species of Shirleyrhynchus. Shirleyrhynchus panamensis n. sp. possesses unique morphological characteristics that clearly allocate it to the genus and separate it from congeners. It has been possible to provide an amended generic diagnosis and an identification key for the species of Shirleyrhynchus. Previous molecular phylogenetic studies on trypanorhynchs (Palm et al., 2009; Olson et al., 2010) included a specimen identified as $S$. aetobatidis. The molecular voucher has been re-observed revealing the misidentification of this specimen with an entirely unrelated eutetrarhynchid species, Parachristianella indonesiensis Palm, 2004.

\section{Materials and methods}

Specimens studied were collected from two species of stingrays, the Panamic stingray Urotrygon aspidura (Jordan \& Gilbert) (Myliobatiformes, Urotrygonidae) and the Pacific chupare Himantura pacifica (Beebe \& Tee-Van) (Myliobatiformes: Dasyatidae). Host specimens were obtained from the Golfo de Montijo in the Eastern Pacific Ocean off Palo Seco and Cébaco Island, Veraguas Province, Panama in January 2015 using gill nets and spear guns. Immediately after capture, stringrays were 
sacrificed, the spiral intestines removed, opened with a mid-ventral incision and one half fixed in $10 \%$ seawater-buffered formalin solution for morphological studies and the second half in $95 \%$ ethanol for molecular analyses. The samples fixed with formalin were subsequently transferred to $70 \%$ ethanol for long-term storage. After a careful observation of the spiral intestine halves fixed with pure ethanol no additional specimens were recovered. Trypanorhynch specimens recovered from the intestine were cleaned from host mucus manually using a small brush and selected for whole mount preparation and scanning electron microscopy (SEM). Morphological vouchers were stained with Delafield's hematoxylin, dehydrated in a graded ethanol series, cleared in methyl salicylate and mounted in Canada balsam. Line drawings of whole mounted specimens were made using an Olympus BX-51 light microscope with a drawing attachment and DIC optics.

Measurements are all in micrometres $(\mu \mathrm{m})$ and are given as the range followed by the mean and the number of specimens measured (if $n \geq 3$ ) in parentheses. Abbreviations for the metrical features of Table 1 are as follows: SL, scolex length; PBO, pars bothrialis length; PVA, pars vaginalis length; PBU, pars bulbosa length; PBU W, pars bulbosa width; PPBU, pars postbulbosa length; BL, bulb length; BW, bulb width; TWS, tentacle width at basal swelling; TWM, tentacle width in metabasal region; PVA:PBO, length ratio of pars bothrialis to pars vaginalis; $\mathrm{PBU}: \mathrm{PBO}$, length ratio of pars bothrialis to pars bulbosa. Specimens for SEM were dehydrated in a graded ethanol series, placed in half 95\% ethanol and half hexamethyldisilazane (HMDS) followed by pure HMDS and allowed to air-dry. They were mounted on stubs with carbon tape and coated with gold in a SCD-005 sputter coater (Bal-tec AG, Balzers, Liechtenstein). Scanning electron micrographs were taken with a Sigma VP field emission scanning electron microscope (Carl Zeiss AG, Oberkochen, Germany). Terminology for morphological characteristics and the oncotaxy follow Pintner (1913), Dollfus (1942) and Campbell \& Beveridge (1994), terminology for microtriches follows Chervy (2009). Museum material of S. aetobatidis deposited in the Naturhistorisches Museum in Vienna (Austria), the molecular voucher deposited in the Lawrence R. Penner collection in Storrs (USA) and the typeseries of S. butlerae deposited in the South Australian Museum in Adelaide (Australia) have been observed for comparative purposes. Museum abbreviations used herein are as follows: LRP, Lawrence R. Penner Parasitology Collection, University of Connecticut, Storrs, CT, USA; MIUP, Museu de Invertebrados G.B. Fairchild, Estafeta Universitaria, Universidad de Panamá, Panama; MZUSP, Museu de Zoologia da Universidade de São Paulo, São Paulo, Brazil; USNM, National Museum of Natural History, Washington D.C., Virginia, USA; SAM, South Australian Museum, Adelaide, Australia; VNMH, Naturhistorisches Museum, Vienna, Austria. Additional information on the host specimens and locality records (i.e. PN15) can be accessed via the Global Cestode Database 
at http://tapewormdb.uconn.edu/. Collecting permits were issued to Dr. F. P. L. Marques (University of São Paulo) from the Autoridad Nacional del Ambiente (ANAM, Panama) (Permit No. SE/A-10114 issued 16 DEC 2014).

\section{Genus Shirleyrhynchus Beveridge \& Campbell, 1988}

\section{Amended diagnosis}

Shirleyrhynchidae Campbell \& Beveridge, 1994. Scolex elongate, acraspedote; maximum width at level of pars bothrialis. Four bothria, ovate, narrow, with free posterior margins, rims thickened. Pars vaginalis longer than pars bothrialis; tentacle sheaths slightly sinuous. Prebulbar organs present. Bulbs elongate. Retractor muscle inserts at base of bulb, not associated with gland cells. Pars postbulbosa short. Tentacular armature typical heteroacanthous. Hooks highly heteromorphous, some hollow in basal armature, solid in metabasal armature; hook files 1 and 1' slightly separated. Metabasal armature with seven hooks per principle row; similar or dissimilar hooks on opposing principle rows; orientation of principle rows variable, commencement from antibothrial, external or bothrial surfaces to bothrial, internal or antibothrial surfaces, respectively. Characteristic basal armature present, with slight basal swelling; basal swelling with two or four characteristically shaped hooks. Strobila (unknown for S. aetobatidis and S. panamensis n. sp.) acraspedote, with numerous segments. Genital pores marginal, pre-equatorial, irregularly alternate. Cirrus-sac pyriform; cirrus armed; seminal vesicles absent. Testes medullary, preovarian, in two longitudinal columns, in single layer. Vagina enters genital atrium posterior to cirrus-sac. Ovary at posterior extremity of segment; tetra-lobed. Vitelline follicles circumcortical. Uterus simple, tubular, extends to anterior extremity of segment; uterine pore present. Eggs spherical. Parasitic in eagle rays (Myliobatiformes: Myliobatidae), stingrays (Myliobatiformes: Dasyatidae) and American round stingrays (Myliobatiformes: Urotrygonidae). Type-species: S. butlerae Beveridge \& Campbell, 1988.

\section{Shirleyrhynchus panamensis n. sp.}

Type-host: Urotrygon aspidura (Jordan \& Gilbert) (Myliobatiformes: Urotrygonidae) (PN15-44, PN15-45, PN15-46). 
Type-locality: Eastern Pacific Ocean (Golfo de Montijo) off Palo Seco, Veraguas, Panama ( $\left.7^{\circ} 34^{\prime} 33.5^{\prime \prime} \mathrm{N}, 81^{\circ} 00^{\prime} 42.8^{\prime \prime} \mathrm{W}\right)$.

Additional locality: Eastern Pacific Ocean (Golfo de Montijo) off Isla Cebaco (Playa de Caleta), Veraguas, Panama (7²9'37.9"N, 8113'21.9"W).

Site in host: Spiral intestine.

Prevalence: $U$. aspidura: $21 \%$ (in 3 out of 14 hosts examined); H. pacifica: $9 \%$ (in 1 out of 11 hosts examined).

Intensity: 1-3.

Type-material: Holotype (MIUP-LAV-002). Paratypes (USNM Nos 1298205-1298206, MZUSP No 7766).

Etymology: The species name 'panamensis' relates to the country where this species originated.

\section{Description (Figs. 1-5)}

[Based on 4 whole-mounts; 2 specimens used for SEM observation]. Cestodes small, immature, without developed strobila (Figs. 1A, 4A, B). Scolex acraspedote (Figs. 1A, 4A, B), 3,890-4,055 $(3,989 ; \mathrm{n}=4)$; maximum width at level of pars bothrialis. Tegument width $5-10(7 ; \mathrm{n}=4)$. Pars bothrialis 360-500 (450; $\mathrm{n}=4)$ long, 530-700 (633; n = 4) wide (Figs. 1B, 4C, D), covered with gladiate spinitriches and capilliform filitriches between bothria in dorso-ventral view (Fig. 4I) and acicular to capilliform filitriches between bothrial pairs in lateral view (Fig. 4H). Bothria 4 in number, narrow, ovate (Figs. 1B, 4C), 425-490 (457; $\mathrm{n}=5)$ long, 160-205 (187; $\mathrm{n}=5$ ) wide in midline; distal bothrial surface covered with gladiate spinitriches (Fig. 4E, G); proximal bothrial surface covered with acicular to capilliform filitriches (Fig. 4F). Pars vaginalis 1,730-1,930 $(1,830 ; n=4)$ long, 395-495 (463; n = 4) wide in mid-line (Figs. 1A, 4A, B), covered with capilliform filitriches (Fig. 4J); tentacular sheaths slightly sinuous (Fig. 1A), 90-125 $(110 ; n=16)$ in diameter. Pars bulbosa 1,960-2,220 (2,081; $\mathrm{n}=4)$ long, 445-515 (478; $\mathrm{n}=4)$ wide. Prebulbar organs present (Fig. 1D), 50-60 (55; $\mathrm{n}=10)$ long, 30-35 (34; $\mathrm{n}=10)$ wide. Bulbs elongate, thick-walled, muscular (Fig. 1A, C, D), 1,920-2,220 (2,075; $\mathrm{n}=14)$ long, 185-245 (211; $\mathrm{n}=14)$ wide; wall of bulb 15-30 (23; $\mathrm{n}$ = 16) thick (Fig. 1D); retractor muscle originates at posterior end of bulb, very thick (Fig. 1A, C, D), 25-40 (30; $\mathrm{n}=16)$ wide; gland-cells absent. Bulb width/length ratio $1: 8.6-11.6(1: 9.9 ; \mathrm{n}=14)$. Pars postbulbosa short, 0-230 (78; $\mathrm{n}=4$ ) long (Fig. 1A). Scolex ratio (pars bothrialis : pars vaginalis : pars bulbosa) $1: 3.5-5.2: 4.1-6.0(1: 4.1: 4.7 ; \mathrm{n}=4)$, width/length ratio of individual scolex regions (width : pars bothrialis length : pars vaginalis length : pars bulbosa length) $1: 2.1-3.1$ 
: 3.6-4.7:3.8-4.6(1:2.5:4.0:4.4; $\mathrm{n}=4)$.

Partially everted tentacles 415-770 (594; $n=4)$ long, with slight basal swelling. Tentacle width 75-110 $(93 ; n=6)$ at base, $90-110(102 ; n=5)$ at basal swelling, $90-95(93 ; n=4)$ in metabasal armature (Figs. 2A-D, 3B, 5A, B). Armature typical heteroacanthous, heteromorphous (Figs. 2A, B, D, 5A-D, F, H); hooks either hollow or solid in basal armature, exclusively solid in metabasal armature (Figs. 2A-D, 3A, B).

Basal armature characteristic, consisting of 6 to 8 rows of highly heteromorphous hooks forming complete or partial rows around tentacle (Figs. 2A-D, 3B, 5A-C, G). Bothrial surface with highly heteromorphous hooks in 8 rows (Figs. 2D, 5B); hooks of rows 1 and 2 uncinate, small (Figs. 2D, 5B), 30-40 (34; $n=5)$ long, base 18-28 (22; $n=5)$ long; hooks in rows 3 to 5 falcate, larger (Figs. 2D, 5B), 30-47 (38; $\mathrm{n}=8)$ long, base 7-17 $(12 ; \mathrm{n}=8)$ long, becoming larger with extended base towards external surface; hooks in rows 6 and 7 falcate, hollow, enlarged, with recurved tips (Figs. 2D, 3A, 5B, M), 40-51 (45; $\mathrm{n}=4)$ long, base 11-25 (18; $\mathrm{n}=4)$ long, largest hook in center of row 7; single, falcate hook with recurved tip and very narrow base in row 8 (Figs. 2D, 3A, 5B), 30 $(n=1)$ long, base $6(n=1)$ long. External surface with highly heteromorphous hooks in 7 rows (Figs. 2A, D, 5A, G); hooks of rows 1 and 2 uncinate (Figs. 2A, D, 5A, G), 28-41 (33; n = 9) long, base 20-31 (26; $\mathrm{n}=9)$ long; hooks of rows 3 and 4 triangular, with transverse base (Figs. 2A, D, 3A, 5A, G), 34-40 (37; n = 7) long, base 14-38 (26; $\mathrm{n}=7)$ long, becoming narrower, falcate, with well-developed posterior heel (Figs. 2A, D, 5A, G), 33-43 (39; n =4) long, base 13-18 (16; n = 4) long; hooks of row 5 triangular, with transverse, curved base (Figs. 2D, 3A, 5A, G), 41-47 (44; n = 3) long, base 28-30 (29; $n=3)$ long, becoming more uncinate towards antibothrial surface (Figs. 2A, 5A, G), 30-31 ( $\mathrm{n}=2)$ long, base 26-30 (n=2) long; row 5 ends with 2 characteristic hooks (Figs. 2A-D, 3A, B, 5A, B, G, I, K), displaced anteromedially on external surface; posterior characteristic hook (= CH1) hollow, with very wide base, with sharp tip (Figs. 2A-D, 3A, B, 5A, B, G, I, K), 47-51 (48; $n=3)$ long, base length 21-24 (23; $n=3)$, base width 55-60 (57; $n=4)$; anterior characteristic hook $(=\mathrm{CH} 2)$ hollow, more compact, base narrower, with slightly rounded tip (Figs. 2A-D, 3A, B, 5A, B, G, I, K), 40-50 (44; n = 3) long, base length 23-24 (23; n = 3), base width 31-42 (38; $\mathrm{n}=4)$; hooks in row 7 uncinate, displaced anteromedially (Figs. 2A, D, 5A), 17$30(23 ; \mathrm{n}=10)$ long, base 11-21 (15; $\mathrm{n}=10)$ long. Internal surface with highly heteromorphous hooks in 8 rows (Figs. 2B, C, 5B, C); hooks of rows 1 and 2 uncinate (Figs. 2B, C, 5B, C), 27-34 $(30 ; n=5)$ long, base $18-23(20 ; n=5)$ long; hooks of rows 3 and 4 falcate, with well-developed posterior heel (Figs. 2B, C, 3A, 5B, C), 35-43 (39; n = 4) long, base 16-20 (18; $\mathrm{n}=4)$ long, becoming falcate, larger towards antibothrial surface (Figs. 2B, C, 5C), 38-45 (43; n = 4) long, base 
16-18 $(18 ; \mathrm{n}=4)$ long; hooks of row 5 spiniform, with very narrow base (Figs. 2B, C, 5C), $37(\mathrm{n}=$ 1) long, base $6(n=1)$ long, becoming falcate, larger towards antibothrial surface (Figs. 2B, C, 5C), 43-47 (45; $n=3)$ long, base 13-18 $(16 ; n=3)$ long; hooks of row 6 large, falcate, with narrow base and recurved tip (Figs. 2B, C, 5C), 44-53 (48; $n=6)$ long, base 10-20 (15; n =6) long, followed by a single, falcate hook, with characteristic triangular base (Figs. 2B, C, 5C), 30-33 (n=2) long, base 14-16 ( $\mathrm{n}=2)$ long; single hook of row 7 falcate, smaller, with narrow base and recurved tip (Fig. 2B, C), 28-38 (34; $n=4)$ long, base 7-9 $(8 ; n=4)$ long; row 8 of internal surface with 2 characteristic hooks (Figs. 2B-D, 3A, 5A-C, E, J, K, N), displaced anteromedially on internal surface, opposite characteristic hooks $\mathrm{CH} 1$ and $\mathrm{CH} 2$ (Fig. 5L); posterior characteristic hook $(=\mathrm{CH} 3$ ) hollow, with narrow, rounded base, sharp tip (Figs. 2B-D, 3A, 5C, J), 43-53 (49; n = 3) long, base length 9-18 (13; $\mathrm{n}=3)$; anterior characteristic hook $(=\mathrm{CH} 4)$ hollow, with characteristically round tip, base widened (Figs. 2B-D, 3A, 5A-C, E, J, K, N), 47-64 (58; n = 4) long, base length 17-29 $(25 ; n=4)$, base width $20-45(n=2)$. Antibothrial surface with highly heteromorphous hooks in 6 rows (Figs. 2B, C, 5A, C, E, G); hooks of rows 1 to 3 uncinate (Figs. 2C, 5A, C, E, G), 23-40 (29; n $=11)$ long, base $14-30(21 ; n=11)$ long; hooks of rows 4 to 6 falcate, with characteristically triangular base (Figs. 2B, C, 5A, C, E, G), 28-55 (40; n = 5) long, base 11-23 (17; n = 5) long, followed by large, falcate hooks (Figs. 2B, C, 5A, C, E, G), 44-50 (48; n = 5) long, base 14-24 (18; $n=5$ ) long. Principle hook rows of metabasal armature commence from hook row 9 of bothrial surface (Figs. 2A-D, 5A-C).

Metabasal tentacular armature typical heteroacanthous (Figs. 2A, B, D, 5A-D, F, H); principle hook rows arranged in ascending half spiral rows, begin on bothrial tentacular surface (Figs. 2A, B, 5B, D, H) and terminate on antibothrial tentacular surface in inverted ' $\mathrm{V}$ '-formations (Figs. 2C, 5A, F); 7 heteromorphous hooks per half spiral row (Figs. 2A, B, D, 5A-D, F, H); hooks 1 and 1' slightly separated (Fig. 5B, D, H); hook couplets of opposing hook rows differ in shape and size (Figs. 3A, 5B, D, H). Hooks 1 large, uncinate, with well-developed posterior heel (Figs. 3A, 5B, D), constantly increasing in size in early metabasal armature (Figs. 3A, 5B), 30-37 (33; n = 3) long, base 21-25 $(23 ; n=3)$ long in hook row 9, 44-47 $(n=2)$ long, base 34-35 (n=2) long in hook row 10, 63-68 (66; $n=3)$ long, base 45-50 (47; $n=3)$ long in hook row 11, $83(n=1)$ long, base 63-65 $(\mathrm{n}=2)$ long in hook row 12, 85-100 $(92 ; \mathrm{n}=11)$ long, base 61-78 (72; $\mathrm{n}=11)$ long in hook row 13 onwards; hooks 1' large, uncinate, more erect, with less-developed posterior heel (Figs. 3A, 5B, D), constantly increasing in size in early metabasal armature (Figs. 3A, 5B), $28(\mathrm{n}=1)$ long, base $16(\mathrm{n}$ =1) long in hook row 9, 33-36 (n=2) long, base 19-20 (n=2) long in hook row 10, $59(\mathrm{n}=1)$ long, base $43(n=1)$ long in hook row 11, $63(n=1)$ long, base $40(n=1)$ long in hook row 12, 77- 
$79(\mathrm{n}=2)$ long, base 51-61 ( $\mathrm{n}=2)$ long in hook row 13 onwards; hooks 2 falcate, erect, with very wide base, with slightly recurved tip (Figs. 3A, 5B, D), with constant size from hook row 13 onwards, 85-100 (93; $\mathrm{n}=7)$ long, base 48-56 (52; $\mathrm{n}=7)$ long; hooks 2' falcate, smaller, narrower, less erect, with narrower, solid base, with slightly recurved tip (Figs. 3A, 5B, D), with constant size from hook row 13 onwards, 62-71 ( $\mathrm{n}=2)$ long, base 17-31 ( $\mathrm{n}=2)$ long; hooks 3 falcate, erect, with narrow base (Fig. 3A), with slightly recurved tip, with constant size from hook row 11 onwards, 67$80(73 ; n=5)$ long, base 20-25 (23; $n=5)$ long; hooks 3' falcate, smaller, less erect, with wider base, with slightly recurved tip (Fig. 3A), with constant size from hook row 11 onwards, 52-62 (56; $\mathrm{n}=5)$ long, base 24-30 (27; $\mathrm{n}=5)$ long; hooks 4(4') to 5(5') falcate, with narrow bases (Figs. 2A, B, 3A); hooks 5(5') to 7(7') displaced anteromedially (Fig. 5A, F); hooks 4 with slightly recurved tip (Figs. 2A, 3A), 48-82 (60; $n=4)$ long, base 21-24 (23; $n=4)$ long; hooks 4' with slightly recurved tip (Figs. 2B, 3A), 61-85 (73; $\mathrm{n}=6)$ long, base 14-25 $(21 ; \mathrm{n}=6)$ long; hooks 5 erect, with straight tip (Figs. 2A, 3A), 54-66 (59; $\mathrm{n}=4)$ long, base 17-19 (18; $\mathrm{n}=4)$ long; hooks 5' erect, with straight tip (Figs. 2B, 3A), 56-68 (64; $n=6)$ long, base 13-20 (17; $n=5)$ long; hooks 6 falcate (Figs. 2A, 3A), 40-50 (44; $n=6)$ long, base 13-21 (16; $n=6)$ long; hooks 6' falcate (Figs. 2B, 3A), 40-61 (50; $\mathrm{n}=4)$ long, base 11-20 (14; $\mathrm{n}=4)$ long; hooks 7 falcate to uncinate (Figs. 2A, D, 3A, 5A, F), with well-developed posterior heel, 37-46 (43; $n=7)$ long, base 17-24 (20; $n=7)$ long; hooks 7' falcate to uncinate, with less-developed posterior heel (Figs. 2B, D, 3A, 5A, F), 38-47 (41; n = 5) long, base $11-21(16 ; \mathrm{n}=5)$ long.

Strobila unknown.

\section{Remarks}

The present specimens belong to the genus Shirleyrhynchus Beveridge \& Campbell, 1988 due to several morphological characteristics, i.e. the presence of four, ovate bothria, presence of prebulbar organs, retractor muscles attached to the posterior part of the bulbs, lack of gland-cells and a typical heteroacanthous, heteromorphous tentacular armature. They differ from congeners in the size of the scolex (mean < $4.0 v s>4.7 \mathrm{~mm}$; Table 1), a smaller pars vaginalis (mean $1.8 v s>2.7 \mathrm{~mm}$; Table 1), heteromorphous hook couplets on opposing principle rows ( $v s$ homeomorphous metabasal hook couplets on opposing principle rows), an orientation of principle rows from the bothrial to the antibothrial surface ( $v s$ an orientation from antibothrial to bothrial in S. butlerae and from external to internal surfaces in $S$. aetobatidis, see below) and differently shaped hooks on both the basal and metabasal tentacular armature. The present specimens are thus considered as a new species. 
Unfortunately, the description of the new species is partial and entirely based on the morphology of the scolex and the oncotaxy of the tentacular armature. All specimens recovered from the two host species were immature and lack any segmentation. They have also been obtained in relatively few numbers (i.e. only six specimens in total), with a very low intensity (i.e. with a maximum of three worms per host individual) and a low prevalence (i.e. $21 \%$ of $U$. aspidura and 9\% of $H$. pacifica). The new species is considered a rare and uncommon representative of the Shirleyrhynchidae, which could be a result of a complex life-cycle with several intermediate host stages or a slow maturation period. Specimens have been found in parts of the spiral valve that have been fixed with formalin. For that reason an identification and classification based on molecules is currently not possible. Nonetheless, the characteristic tentacular armature and the features of the scolex are unique among the trypanorhynch cestodes and a generic placement could be achieved without difficulties.

Until now, the trypanorhynch genus Shirleyrhynchus has been monotypic. The resurrection of S. butlerae (see below) and the description of a third species from Central America changes the monotypic status of the genus and may lead to the subsequent discovery of additional species from geographical regions and host species that have not yet been studied sufficiently.

\section{Shirleyrhynchus aetobatidis (Shipley \& Hornell, 1906) Beveridge \& Campbell, 1998}

Syns Tetrarhynchus aetobatidis Shipley \& Hornell, 1906; Tentacularia aetobatidis (Shipley \& Hornell, 1906) Southwell, 1929.

Material examined: Holotype (accession No. VNHM 2099) (Fig. 6); hologenophore (LRP4275;

Olson et al., 2010).

Type-host: Aetobatus narinari (Euphrasen) (Myliobatiformes: Myliobatidae).

Additional host: Neotrygon kuhlii (Müller \& Henle) (Myliobatiformes: Dasyatidae). Type-locality: Indian Ocean (Gulf of Manaar) off Dutch Bay Spit, Sri Lanka. Additional locality: Indian Ocean (Gulf of Manaar) off 'Ceylon Pearl Banks' (unknown location). Site in host: Spiral intestine.

\section{Remarks}


morphological characteristics stated for this species was the width of the pars bulbosa, supposedly much wider than the remainder of the scolex and the strobila. The holotype deposited in the Naturhistorisches Museum in Vienna displays this characteristic. However, this might be the result of flattening or compression of the worm on the microscope slide with the cover slip or might have happened during its collection. The line drawing of the anterior part of the worm provided by Shipley \& Hornell (1906; p. 49, figure 24) illustrates the pars vaginalis and the pars bulbosa of a similar width, which furthermore refutes this statement. This species was transferred into Shirleyrhynchus by Beveridge \& Campbell (1998) due to apparent morphological similarities to the type-species, S. butlerae Beveridge \& Campbell, 1988. Beveridge \& Campbell (1998) did not observe major morphological differences to the type-species apart from the host choice and features of the oncotaxy, such as differences in hook sizes and the shape of enlarged hooks on the basal tentacular surface (see Beveridge \& Campbell, 1998). Therefore, they (1998) synonymised $S$. butlerae with $S$. aetobatidis. However, recent observations of the holotype of $S$. aetobatidis and the type-series of $S$. butlerae provide new insights on their morphology which ultimately questions this decision (see below). The holotype of $S$. aetobatidis is the only extant specimen of this species.

Beveridge \& Campbell (1998) re-described S. aetobatidis and provided metrical data of the scolex and the tentacular armature. However, several features stated by these authors seem to be erroneous and need clarification. The scolex of $S$. aetobatidis has been reported to be $6.08 \mathrm{~mm}$ long (see Beveridge \& Campbell, 1998). However, calculating the scolex size from the data of individual scolex regions (i.e. pars vaginalis, pars bulbosa and pars postbulbosa) would add up to a scolex length of $6.3 \mathrm{~mm}$. Observing the holotype reveals a scolex length of $6.3 \mathrm{~mm}$ (see Table 1). Individual body regions stated by Beveridge \& Campbell (1998) are in accordance with the metrical data of the holotype.

This study provides additional line drawings of different tentacular surfaces of the holotype of $S$. aetobatidis (Fig. 6A-C). The metabasal tentacular armature of $S$. aetobatidis was described by Beveridge \& Campbell (1998) to contain eight hooks per principle row, each of which was measured and illustrated (Beveridge \& Campbell, 1998; figure 3). However, the present study reveals a metabasal armature of $S$. aetobatidis that consists of only seven hooks per principle row (Fig. 6C). Beveridge \& Campbell (1998) implied that hooks 7(7') and 8(8') were of the same size for both the hook length and base length, uncinate and slightly larger than hooks 6(6'). However, there is only a single, uncinate hook couplet [i.e. hooks $7\left(7^{\prime}\right)$ ] present in the holotype and the authors might have inadvertently adjusted the oncotaxy to representatives of $S$. butlerae (see below). Therefore, the drawings provided by Beveridge \& Campbell (1998) have to be amended as follows: the hook 
labelled as hook 8 (Beveridge \& Campbell, 1998; figure 2) now becomes hook 7' of the opposing principle row and hook 8 (Beveridge \& Campbell, 1998; figure 3) in fact resembles hooks 7 and 7', whereas hooks 6 and 7 resemble the same couplet [i.e. hooks 6(6')]. Only a single measurement for hook length and base length was provided by Beveridge \& Campbell (1998) for each hook couplet of both opposing principle rows. These measurements differ significantly from the individual length and base length measurements of hooks provided for the Australian specimens of S. butlerae (Beveridge \& Campbell, 1988), which were on average about two times smaller. This fact, however, did not prevent the authors from synonymizing both species. Due to the large variation in hook sizes they have been measured again and it became apparent that Beveridge \& Campbell (1998) must have made a simple error in calibration and that the hook sizes are very similar to the ones known for S. butlerae (see Table 2). New measurements of the hooks of S. aetobatidis are provided in Table 2 and are compared with the hook sizes of $S$. butlerae. On average, hooks 1(1') and hooks 7(7') as well as the base length of hooks 2(2') are larger than the ones of S. butlerae (see Table 2). It is also worth mentioning that hooks 6(6') and 7(7') are displaced anteromedially (Fig. 6C), similar to the pattern of the terminal hooks of $S$. butlerae. The orientation of principle hook rows also differs in both species. Principle hook rows of $S$. aetobatidis start on the external and terminate on the internal tentacular surface, whereas S. butlerae was reported to possess an orientation from the 'internal' to the 'external' tentacular surface (Beveridge \& Campbell, 1988).

The basal armature of $S$. aetobatidis illustrated by Beveridge \& Campbell (1998) is fragmented and several hooks seem to be lost (Beveridge \& Campbell, 1998; figure 2). The present study presents the bothrial surface of the basal armature (Fig. 6A), which consists of 10 rows of hooks, with only two characteristic hooks situated in hook row 8 (Fig. 6A). These two characteristic hooks on the slight basal swelling of $S$. aetobatidis (Fig. 6A; labelled as $\mathrm{CH} 1$ and $\mathrm{CH} 2$ ) are situated on the internal surface. The presence of characteristically shaped hooks on the basal armature seems to be a consistent morphological characteristic of species of Shirleyrhynchus. In S. panamensis four characteristic basal hooks are present (Figs. 2A-D, 3A, B, 4C, D, 5A-C, E, G, I-K, N), two on both the bothrial and antibothrial tentacular surfaces. Shirleyrhynchus butlerae also presents four characteristically shaped hooks, which have been drawn but were not mentioned in its original description (Beveridge \& Campbell, 1988; figures 11, 12).

A less pronounced basal swelling has been detected in the holotype and was measured in the present study (see Table 1). Although only slightly wider than the diameter of the metabasal armature, this feature has not been recorded previously and a basal swelling was described as being absent (see Beveridge \& Campbell, 1998). 
A single specimen of Shirleyrhynchus labelled and identified previously as 'S. aetobatidis' has been included in two recent molecular phylogenetic studies (Palm et al., 2009; Olson et al., 2010). The molecular voucher specimen is deposited in the Lawrence R. Penner collection at the University of Connecticut (under accession number LRP4275). It has been collected from Himantura uarnak 1 (sensu Naylor et al., 2012) from the Celebes Sea off the Malaysian part of Borneo (collection code BO-82). This location is of a particular interest since it is situated between the type-locality of $S$. aetobatidis (i.e. Sri Lanka) and the known area of distribution of S. butlerae in Australia. Both analyses based on molecular data of ribosomal genes placed the specimen in a clade consisting of two species of Parachristianella Dollfus, 1946, Pa. baverstocki Beveridge, 1990 and Pa. indonesiensis Palm, 2004. This placement of eutetrarhynchid species with a single representative of the Shirleyrhynchidae could not be explained at that time and seemed highly uncertain. In order to reveal the correct species diagnosis, the hologenophore (accession no. LRP4275) has been re-observed. Microscopical observations revealed the presence of gland cells and two bothria, which would immediately place it within the Eutetrarhynchidae. The scolex size and lengths of individual scolex regions were as follows: scolex $1.89 \mathrm{~mm}$ in length; pars bothrialis $205 \mu \mathrm{m}$ long; pars vaginalis 1,171 $\mu \mathrm{m}$ long; pars bulbosa $718 \mu \mathrm{m}$ long. This represents a scolex size of this specimen that is only $30 \%$ of the size described for S. aetobatidis (i.e. with a scolex length of $6.3 \mathrm{~mm}$ ). The tentacular armature, however, displays the potential cause for the misidentification of this single specimen as $S$. aetobatidis. The basal armature displays two billhooks which (at first glance) resemble the characteristic hooks of $S$. aetobatidis. The metabasal armature is typical heteroacanthous, with about 11 hooks per principle row. These morphological features of the hologenophore would allocate it to Pa. indonesiensis described by Palm (2004), however, with slightly smaller scolex proportions than in the hologenophore. This is accounted for by the appearance of the scolex, which is largely stretched and extended. In a study on the trypanorhynch cestode fauna of Borneo, Schaeffner \& Beveridge (2014) detected Pa. indonesiensis in a total of 16 different host species of several elasmobranch families, making it a common and prevalent species in the South-east Asian realm. The misidentification of the hologenophore raises serious questions on the accounts of 'S. aetobatidis' in five different host species (see Schaeffner \& Beveridge, 2014) and the actual presence of this species in this biogeographical region. For the time being these accounts have to be regarded with suspicion. 
Syn. Shirleyrhynchus aetobatidis (Shipley \& Hornell, 1906) Beveridge \& Campbell, 1998.

Material examined: 4 paratypes and 2 slides with detached tentacles from type-series (SAM AHC22773).

Type-host: Dasyatis fluviorum Ogilby (Myliobatiformes: Dasyatidae).

Additional hosts: Pastinachus atrus (Macleay) (Myliobatiformes: Dasyatidae).

Type-locality: South Pacific Ocean (Moreton and Deception Bays) off Brisbane, Queensland, Australia.

Additional localities: Timor Sea (Fog Bay), Northern Territory, Australia.

Site in host: Spiral intestine.

Remarks

Beveridge \& Campbell (1988) described S. butlerae, but later synonymised this species with $S$. aetobatidis (Beveridge \& Campbell, 1998) (see above). Recent observations of the type-specimens of $S$. butlerae deposited in the South Australian Museum in Adelaide (Australia) revealed new insights on its morphology and oncotaxy.

Several morphological differences between S. aetobatidis and S. butlerae have been observed within the present study that necessitate the separation of the single specimen from Sri Lanka and the Australian specimens into two independent species. The scolex of S. butlerae is significantly smaller than the one of S. aetobatidis (i.e. mean 4.7 vs $6.3 \mathrm{~mm}$; Table 1). The same applies to the sizes of the muscular bulbs (i.e. mean $1,830 \times 180$ vs 2,300 $\times 480 \mu \mathrm{m}$; Table 1). The most obvious morphological differences are present in the oncotaxy. Specimens of S. butlerae possess four characteristic hooks on the basal swelling, whereas the holotype of S. aetobatidis has only two characteristic hooks at the basal armature of each tentacle (Fig. 6A). Although, the metabasal armature consists of homeomorphous hook couplets in both species, the orientation of principle rows differs. The tentacular diameter of $125 \mu \mathrm{m}$ at the basal swelling and $105 \mu \mathrm{m}$ at the metabasal armature of S. aetobatidis (Fig. 6A-C; Table 1) represents another character differentiating this species from S. butlerae, with much narrower tentacles (90 and $40 \mu \mathrm{m}$, respectively; Table 1). On the basis of these morphological discrepancies $S$. butlerae is hereby resurrected.

Observations of several paratypes of S. butlerae also revealed several morphological characteristics that differ from the original description (Beveridge \& Campbell, 1988) and which are 
amended herein. Shirleyrhynchus butlerae was reported to possess a metabasal tentacular armature with an orientation of hooks from the 'internal' to the 'external' tentacular surface (see Beveridge $\&$ Campbell, 1988). However, specimens of the type-series possess an orientation of principle hooks from the antibothrial to the bothrial tentacular surface. In species possessing four bothria, this feature of the oncotaxy is sometimes very difficult to observe, depending on the orientation of the bothria and placement of the scolex on the microscope slide. Beveridge \& Campbell (1988) supposably relied on Dollfus' (1942) statement that principle hook rows of all trypanorhynchs with a heteroacanthous armature have principle rows starting on the internal and terminating on the external surface. The orientation of principle rows from the antibothrial to the bothrial surface in $S$. butlerae differentiates it from both congeners. Several line drawings of the oncotaxy provided by Beveridge \& Campbell (1988) require amendments. The antibothrial surface with the start of principle rows is illustrated in figures 7 and 10, whereas the termination of principle rows on the bothrial surface is shown in figures 8 and 12 (see Beveridge \& Campbell, 1988). Figure 9 could both illustrate the external or internal tentacular surface of the metabasal armature, whereas figure 11 shows the basal and metabasal region of the internal surface (see Beveridge \& Campbell, 1988).

Another discrepancy in the original description of Beveridge \& Campbell (1988) has been observed in the number of hooks per principle row in the metabasal tentacular armature. The two terminal hooks of principle rows in the metabasal armature were described as being of a rose-thorn shape and almost of the same size [i.e. hooks 7(7') 22-32 $\mu \mathrm{m}$ long, base 18-24 $\mu \mathrm{m}$ long; hooks 8(8') 20-30 $\mu \mathrm{m}$ long, base 16-24 $\mu \mathrm{m}$ long]. Instead of these eight principle hooks described and illustrated in the original description (Beveridge \& Campbell, 1988; figures 8 and 13), the specimens of the type-series only possess a total of seven hooks. Only a single uncinate (i.e. 'rosethorn shaped') hook couplet [i.e. hooks $7\left(7^{\prime}\right)$ ] is present in S. butlerae. This depicts the same situation as stated for $S$. aetobatidis (see above) and the original drawings provided by Beveridge $\&$ Campbell (1988) thus need to be amended. Individual hook couplets 3(3') to 8(8') (Beveridge \& Campbell, 1988; figure 8) now become hooks 2(2') to 7(7'), respectively, with only the last hook couplet [i.e. hooks $7\left(7^{\prime}\right)$ ] being of an uncinate shape. Both uncinate hooks labelled as hook 7 and 8 (Beveridge \& Campbell, 1988; figure 13) in fact resemble the single, most terminal hook 7. The possession of only seven principle hooks per row in the metabasal tentacular armature is consistent with the two other species of Shirleyrhynchus (see above), which possess the same number of principle hooks. The presence of seven principle hooks can, therefore, be considered as a characteristic generic feature for all members of Shirleyrhynchus.

The basal armature of $S$. butlerae has been described to be composed of 10 to 11 rows of 
hooks which are arranged in quincunxes (Beveridge \& Campbell, 1988). Observations of the typeseries revealed a spacing between the smaller basal hooks on the bothrial tentacular surface, which gives the impression that these hooks are arranged in quincunxes. However, different views on internal and external tentacular surfaces clearly show that the basal hooks are arranged in regular rows. Furthermore, Beveridge \& Campbell (1988) illustrated the 'internal', 'antibothrial' and 'external' surfaces of the basal armature of $S$. butlerae in great detail (Beveridge \& Campbell, 1988; figures 10, 11 and 12, respectively). An arrangement of basal hooks in quincunxes is not present in either of the line-drawings. The basal armature thus consists of nine rows in regular V-formations on the 'internal' (= antibothrial), ten rows on the 'antibothrial' (= internal) and ten rows in inverted Vformations on the 'external' (= bothrial) surface (Beveridge \& Campbell, 1988; figures 10, 11 and 12, respectively). Characteristic hooks are situated in hook rows 9 and 10 (figure 11 in Beveridge \& Campbell, 1988) and hook row 10 (figure 12 in Beveridge \& Campbell, 1988). The position of the characteristic hooks seems to be on those surfaces of the tentacles where the principle hook rows in the metabasal armature start and terminate. Two characteristic hooks are thereby situated on both the antibothrial and bothrial tentacular surfaces of $S$. butlerae and $S$. panamensis. The latter, however, has an opposing orientation of the principle rows from the bothrial to the antibothrial surface. Shirleyrhynchus aetobatidis on the other hand, has only two characteristically shaped hooks on the internal tentacular surface, where the principle rows of the metabasal armature terminate.

\section{Key to the species of Shirleyrhynchus}

Due to the absence of segments in the type-species $S$. aetobatidis and in S. panamensis, this key is entirely based on the morphological characteristics of the scolex and the tentacular armature.

1a Scolex > $6 \mathrm{~mm}$ in length; pars vaginalis > $3.7 \mathrm{~mm}$ in length; bulbs $2,300 \times 480 \mu \mathrm{m}$; metabasal tentacular armature with orientation of principle hook rows from external to internal surface; two characteristically shaped hooks on internal surface of slight basal swelling S. aetobatidis (Shipley \& Hornell, 1906)

1b Scolex $<5.2 \mathrm{~mm}$ in length; pars vaginalis $<3.1 \mathrm{~mm}$ in length; bulb length $<2,220 \mu \mathrm{m}$, width $<245 \mu \mathrm{m}$; metabasal armature with different orientation of principle hook rows; four characteristically shaped hooks on slight basal swelling

2a Scolex $>4.3 \mathrm{~mm}$ in length; pars vaginalis $>2.4 \mathrm{~mm}$ in length; metabasal tentacular armature 
with orientation of principle hook rows from antibothrial to bothrial surface; hook couplets similar in shape and size on opposing principle rows

S. butlerae Beveridge \& Campbell, 1988

2b Scolex $<4.1 \mathrm{~mm}$ in length; pars vaginalis $<2.0 \mathrm{~mm}$ in length; metabasal armature with orientation of principle hook rows from bothrial to antibothrial surface; hook couplets dissimilar in shape and size on opposing principle rows in the metabasal armature

S. panamensis n. sp.

\section{Discussion}

Shirleyrhynchus represents a morphologically unique genus, which has changed family affiliations several times since its erection by Beveridge \& Campbell (1988) due to similar characteristics with members of the Gilquiniidae, Tetrarhynchobothriidae, Eutetrarhynchidae and Rhinoptericolidae (see Beveridge \& Campbell, 1988; Campbell \& Beveridge, 1994; Palm, 2004, 2010). Until recently, it was placed in the eutetrarhynchoid family Rhinoptericolidae, together with two monotypic genera (i.e. Rhinoptericola and Cetorhinicola).

A large number of trypanorhynch species have been included in two recent molecular phylogenetic analyses performed by Palm et al. (2009) and Olson et al. (2010). Both studies focused on two ribosomal gene regions (i.e. partial $28 \mathrm{~S}$ rDNA and 18S rDNA) which resulted in similar phylogenetic tree topologies differing substantially from the current classification based on morphology. However, the misidentification of $S$. aetobatidis as the eutetrarhynchid species $P a$. indonesiensis (see above) reduces the number of rhinoptericolid representatives for both studies. Due to the absence of material of species of Shirleyrhynchus for molecular studies, the placement of the three species towards members of the Rhinoptericolidae now becomes ambiguous. Palm et al. (2009) included $R$. megacantha and an unidentified genus (= Unidentified gen. nov. sp. nov.; Hp 47) which was later described by Palm (2010) as Nataliella marcelli Palm, 2010. Olson et al. (2010) only included $R$. megacantha. In general, the analyses resulted in little support for the taxonomic classification of families. Members of the Rhinoptericolidae appeared in a more derived position, sister to the Tentacularioidea. Due to the absence of species of Shirleyrhynchus, the decision made by Palm (2004) to unite the Shirleyrhynchidae with the Rhinoptericolidae can therefore at present neither be confirmed nor negated. Overall, neither of the authors of the two phylogenetic treatments discussed any implications or proposed any nomenclatural changes to the current classification. 
However, on the basis of these molecular phylogenetic results in which 'S. aetobatidis' (now Pa. indonesiensis) nested within the eutetrarhynchoid assemblage, together with members of the Eutetrarhynchidae and Mixodigmatidae, Palm (2010) separated the Rhinoptericolidae (including Rhinoptericola and Nataliella) and resurrected the Shirleyrhynchidae. Palm (2010) stated that this necessitates "a reconsideration of the diagnostic characters of the family as utilised by Palm (2004)" but only provided two characteristics (i.e. "tentacular armature" and "vagina entering the genital atrium anterior to the cirrus-sac") that are shared only by Shirleyrhynchus and members of Parachristianella from the same clade but not with the members of the Mixodigmatidae. Possible explanations to justify the resurrection and verify the validity of the family Shirleyrhynchidae fall short and prove very difficult taking into account the results of the molecular phylogenetic analyses that included the misidentified representative of $S$. aetobatidis. In order to ascertain the taxonomic position and composition of the family Shirleyrhynchidae, several additional species, i.e.

Cetorhinicola acanthocapax Beveridge \& Campbell, 1988 and all the three species of Shirleyrhynchus, remain to be included in a new molecular phylogenetic study. To achieve this, new material of these species should be collected. In order to avoid yet another change to the family affiliations of trypanorhynchs, Shirleyrhynchus and Cetorhinicola are maintained within the ambiguous eutetrarhynchid family, Shirleyrhynchidae until new evidence proves their phylogenetic placement within the Rhinoptericolidae.

In contrast to the ambiguity of the family Shirleyrhynchidae, the present study contributes to the knowledge of species of Shirleyrhynchus which constitutes a unique genus, morphologically distinct and easily distinguishable from other trypanorhynch genera. Novel features are restricted to the oncotaxy and rhyncheal system, such as the presence of a slight basal swelling and seven hooks per principle row in the metabasal tentacular armature and the possession of characteristic hooks on the basal armature (in all species). Hook couplets in the metabasal tentacular armature might be either homeomorphous on opposing principle rows or heteromorphous with different hook shapes and sizes (i.e. in S. panamensis). The fact that two out of three species were described from immature specimens hinders our current knowledge on the segment morphology. Future collections of specimens of $S$. aetobatidis and $S$. panamensis or new species might add additional characters on the segment morphology and might thus alter the current generic diagnosis.

Acknowledgements Special thanks are due to Dr Fernando Marques, Bruna Trevisan (both Universidade de São Paulo, USP, Brazil) and Dr Florian Reyda (State University of New York, 
USA) for their collaboration and sampling efforts in Panama. I am deeply indebted to Dr Ian Beveridge (University of Melbourne, Australia) and Sara Dallarés Villar (Universitat de Barcelona, Spain) for examining and providing essential information on the type-series of $S$. butlerae from the South Australian Museum in Adelaide (I.B.) and examining and providing line drawings of the oncotaxy of the holotype of S. aetobatidis in the Naturhistorisches Museum in Vienna and (S.D.V.). I am very grateful to Dr Janine N. Caira (University of Connecticut, USA) for providing essential photomicrographs of the hologenophore deposited in the L. R. Penner collection at the University of Connecticut. Thanks are due to Dr Leslie Chisholm (South Australian Museum, Australia) for providing specimens of the type-series of $S$. butlerae. Phillip Lenktaitis (USP) operated the scanning electron microscope with a lot of patience for which I am grateful.

Funding Financial support was provided by the post-doctoral fellowship of the Fundação de Amparo á Pesquisa do Estado de São Paulo (FAPESP, Brazil) (No. 2014/10220-0).

\section{Compliance with ethical standards}

Conflict of interest The author declares that he has no conflict of interest.

Ethical approval All applicable institutional, national and international guidelines for the care and use of animals were followed.

\section{References}

Beveridge, I., \& Campbell, R. A. (1988). Cetorhinicola n. g., Shirleyrhynchus n. g. and Stragulorhynchus n. g., three new genera of trypanorhynch cestodes from elasmobranchs in Australian waters. Systematic Parasitology, 12, 47-60.

Beveridge, I., \& Campbell, R. A. (1998). Re-examination of the trypanorhynch cestode collections of A.E. Shipley, J. Hornell and T. Southwell, with the erection of a new genus, Trygonicola, and redescriptions of seven species. Systematic Parasitology, 39, 1-34.

Campbell, R. A., \& Beveridge, I. (1994). Order Trypanorhyncha Diesing, 1863. In: Khalil, L. F., Jones, A., Bray, R. A. (Eds.) Keys to the cestode parasites of vertebrates. Wallingford: CAB International, pp. 51-148. 
Carvajal, J., \& Campbell, R. A. (1975). Rhinoptericola megacantha gen. et sp. n., representing a new family of trypanorhynch cestodes from the cownose ray, Rhinoptera bonasus (Mitchill, 1815). Journal of Parasitology, 61, 1023-1030.

Chervy, L. (2009). Unified terminology for cestode microtriches: a proposal from the International Workshops on Cestode Systematics in 2002-2008. Folia Parasitologica, 56, 199-230.

Dollfus, R.-Ph. (1942). Études critiques sur les Tétrarhynques du Muséum de Paris. Archives du Muséum national d'Histoire naturelle, Paris, 19, 1-466.

Naylor, G. J. P., Caira, J. N., Jensen, K., Rosana, K. A. M., White, W. T., \& Last, P. R. (2012). A DNA sequence-based approach to the identification of shark and ray species and its implications for global elasmobranch diversity and parasitology. Bulletin of the American Museum of Natural History, 367, 1-262.

Olson, P. D., Caira, J. N., Jensen, K., Overstreet, R. M., Palm, H., \& Beveridge, I. (2010). Evolution of the trypanorhynch tapeworms: Parasite phylogeny supports independent lineages of sharks and rays. International Journal for Parasitology, 40, 223-242.

Palm, H. W. (2004). The Trypanorhyncha Diesing, 1863. Bogor: PKSPL-IPB Press, 710 pp.

Palm, H. W. (2010). Nataliella marcelli n. g., n. sp. (Cestoda: Trypanorhyncha: Rhinoptericolidae) from Hawaiian fishes. Systematic Parasitology, 75, 105-115.

Palm, H. W., Waeschenbach, A., Olson, P., \& Littlewood, T. (2009). Molecular phylogeny and evolution of the Trypanorhyncha Diesing, 1863. Molecular Phylogenetics and Evolution, 52, $351-367$.

Pintner, T. (1913). Vorarbeiten zu einer Monographie der Tetrarhynchoideen. Sitzungsberichte der Kaiserlichen Akademie der Wissenschaften in Wien, Mathematisch-Naturwissenschaftliche Klasse, 122, 1-83.

Schaeffner, B. C., \& Beveridge, I. (2014). The trypanorhynch cestode fauna of Borneo. Zootaxa, 3900, 21-49.

Shipley, A. E., \& Hornell, J. (1906). Cestode and nematode parasites from the marine fishes of Ceylon. In: Report to the Government of Ceylon on the Pearl Oyster Fisheries of the Gulf of Manaar. London: Royal Society, pp. 43-96.

\section{Captions to figures}

Fig. 1 Line drawings of Shirleyrhynchus panamensis n. sp. ex Urotrygon aspidura (Jordan \& Gilbert) (PN15-44: A; PN15-46: B-D) from the Golfo de Montijo, Panama. A, Entire specimen, 
lateral view; B, Pars bothrialis, showing two, ovate bothria, dorso-ventral view; C, Bulb; D, Detail of anterior part of bulb

Fig. 2 Line drawings of tentacular armature of Shirleyrhynchus panamensis n. sp. ex Himantura pacifica (Bebe \& Te-Van) (PN15-12: A, B) and Urotrygon aspidura (Jordan \& Gilbert) (PN15-46: C, D) from the Golfo de Montijo, Panama. A, Basal and metabasal tentacular armature, external surface; B, Basal and metabasal tentacular armature, internal (left) to antibothrial surface (right); C, Basal tentacular armature, internal (left) to antibothrial surface (right); D, Basal tentacular armature, bothrial (left) to external surface (right), opposing surface to (C) of same tentacle. Note: Schematic representation of apical part of specimen (top view) provided for each tentacular surface to illustrate aspect and orientation of which tentacle was observed (edited after Palm, 2004). Abbreviation: $\mathrm{CH}$, characteristic basal hook

Fig. 3 Line drawings of tentacular hooks and tentacular armature of Shirleyrhynchus panamensis n. sp. ex Himantura pacifica (Bebe \& Te-Van) (PN15-12: A) and Urotrygon aspidura (Jordan \& Gilbert) (PN15-44: A, B; PN15-46: A) from the Golfo de Montijo, Panama. A, Outlines of tentacular hooks. Note: numbers indicate hooks of opposing rows; Roman numerals indicate number of hook row on tentacle, characteristic hooks are illustrated in lateral view (left) and dorsal view (right); B, Basal armature, external (left) to antibothrial surface (right). Note: Schematic representation of apical part of specimen (top view) provided for tentacular surface to illustrate aspect and orientation of which tentacle was observed (edited after Palm, 2004). Abbreviations: Bo, bothrial surface; In, internal surface; Ex, external surface; $\mathrm{CH}$, characteristic basal hook.

Fig. 4 Scanning electron micrographs of Shirleyrhynchus panamensis n. sp. ex Urotrygon aspidura (Jordan \& Gilbert) (PN15-45: A-J) from the Golfo de Montijo, Panama. A, Entire specimen, dorsoventral view; B, Entire specimen, lateral view; C, Anterior part of scolex, dorso-ventral view, showing narrow, ovate bothria; D, Anterior part of scolex, lateral view; E, Gladiate spinitriches covering distal bothrial surface; F, Acicular to capilliform filitriches covering proximal bothrial surface; G, Gladiate spinitriches covering distal bothrial surface, detailed view; H, Acicular to capilliform filitriches covering pars bothrialis between bothrial pairs in lateral view; I, Gladiate spinitriches and capilliform filitriches covering pars bothrialis between bothria in dorso-ventral view; J, Capilliform filitriches covering pars vaginalis and pars bulbosa, detailed view 
Fig. 5 Scanning electron micrographs of tentacular armature of Shirleyrhynchus panamensis n. sp. ex Urotrygon aspidura (Jordan \& Gilbert) (PN15-45: A-J) from the Golfo de Montijo, Panama. A, Basal and metabasal tentacular armature, external (left) to antibothrial surface (right); B, Basal and metabasal tentacular armature, internal (left) to bothrial surface (right); C, Basal tentacular armature, internal (left) to antibothrial surface (right); D, Metabasal tentacular armature, bothrial (left) to internal surface (right), showing differently shaped hooks 1 and 1' and hooks 2 and 2'; E, Basal tentacular armature, antibothrial surface; F, Distal metabasal tentacular armature, external surface; G, Basal tentacular armature, antibothrial (left) to external surface (right); H, Metabasal tentacular armature, internal surface, showing hooks 1 and 1' only slightly separated; I, Detailed view of basal tentacular armature, external surface, showing characteristic hooks $\mathrm{CH} 1$ (lower) and $\mathrm{CH} 2$ (upper); J, Detailed view of basal tentacular armature, internal surface, showing characteristic hooks $\mathrm{CH} 3$ (lower) and CH4 (upper); K, Detailed view of basal tentacular armature, external surface, showing characteristic hooks $\mathrm{CH} 1$ (lower), $\mathrm{CH} 2$ (middle) and $\mathrm{CH} 4$ (top, unfolding towards internal surface) (side profiles); L, Detailed view on apical part of tentacle, showing characteristic hooks in opposite arrangement; M, Detailed view of basal armature, bothrial tentacular surface, showing enlarged, falcate hooks with recurved tips (side profile); N, Detailed view of basal tentacular armature, internal surface, showing characteristic hook $\mathrm{CH} 4$ (side profile)

Fig. 6 Line drawings of tentacular armature of Shirleyrhynchus aetobatidis (holotype) ex Aetobatus narinari (Euphrasen) from the Gulf of Manaar, Sri Lanka. A, Basal tentacular armature, bothrial surface; B, Metabasal tentacular armature, external surface; C, Metabasal tentacular armature, bothrial surface 


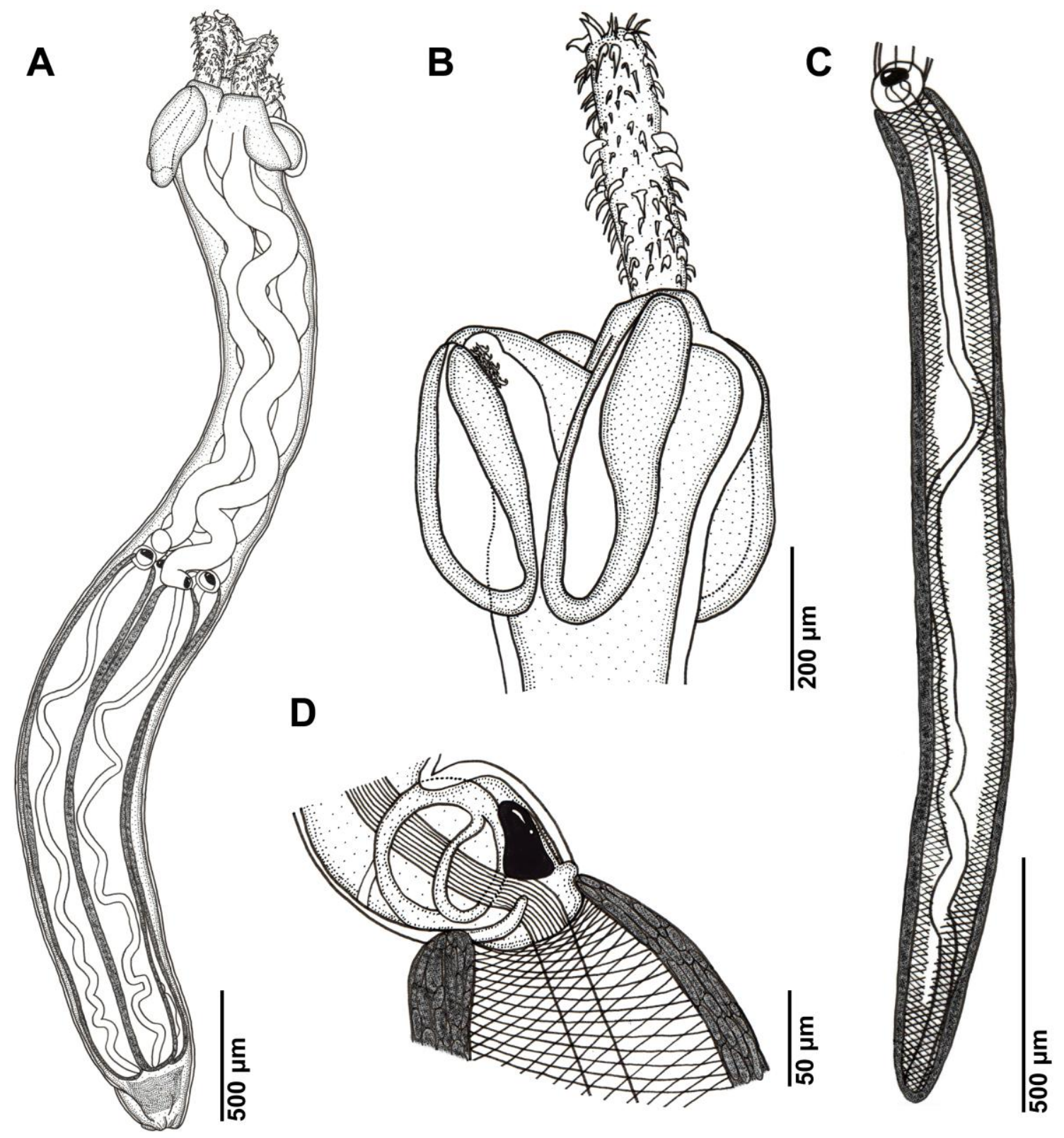




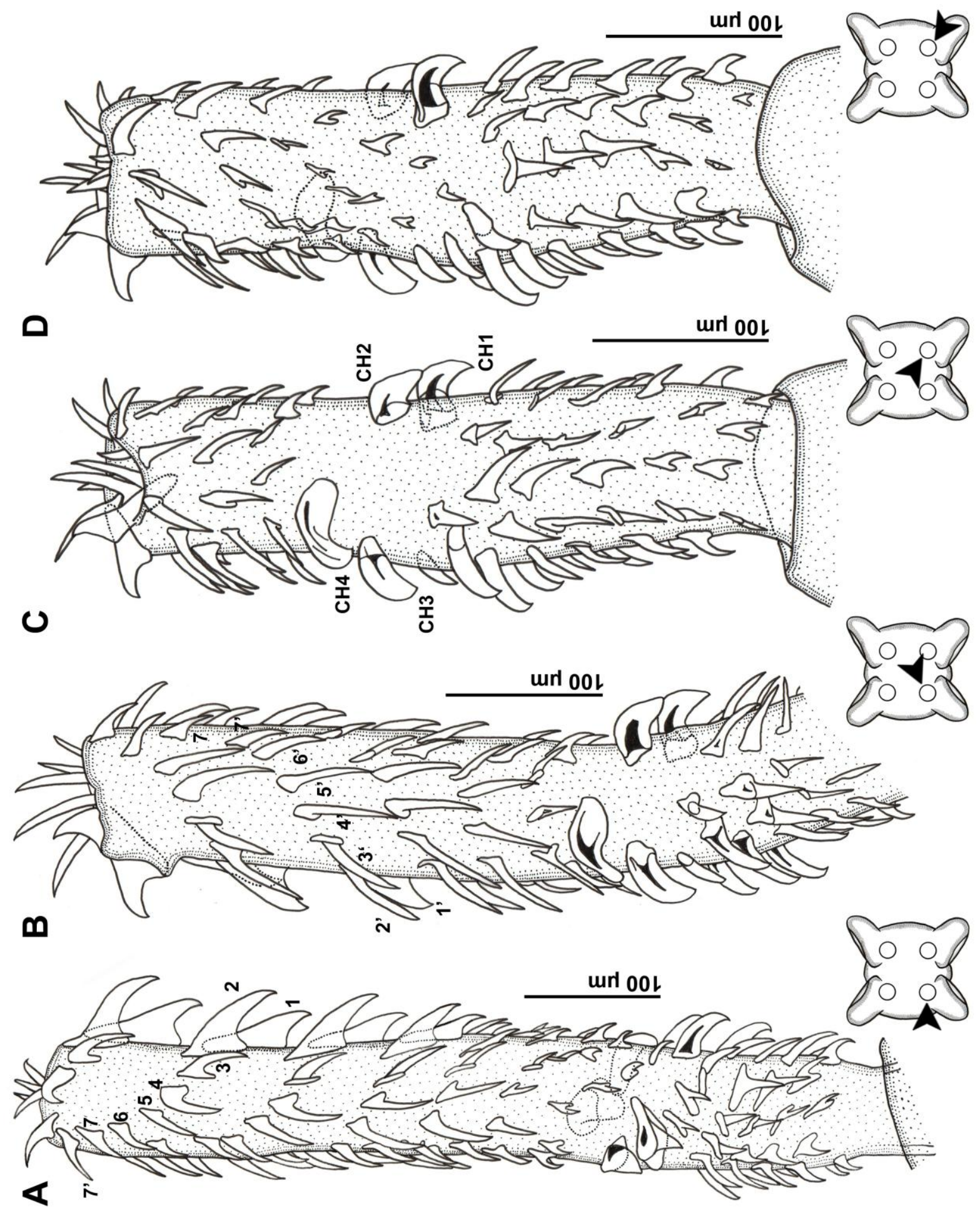



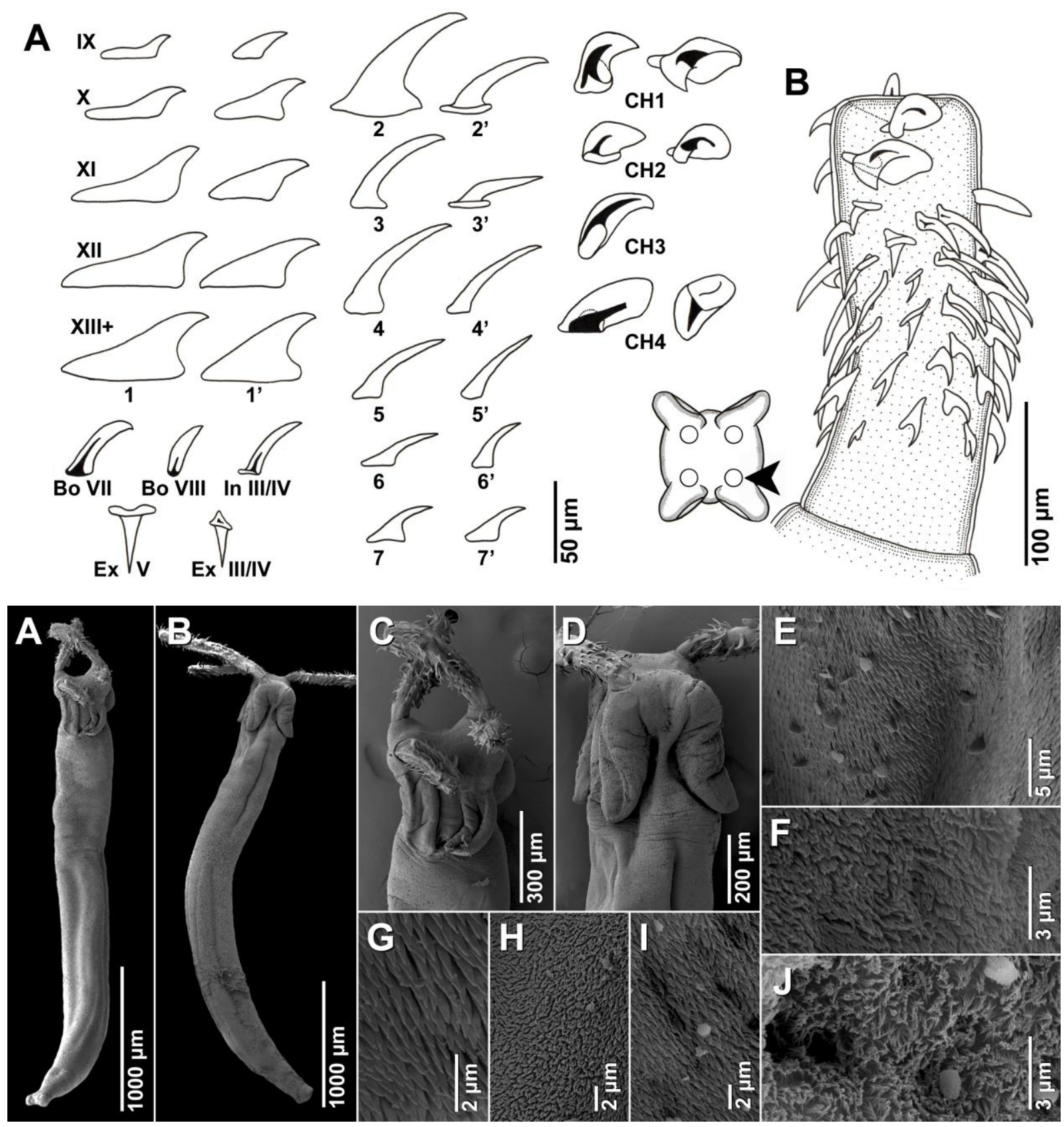


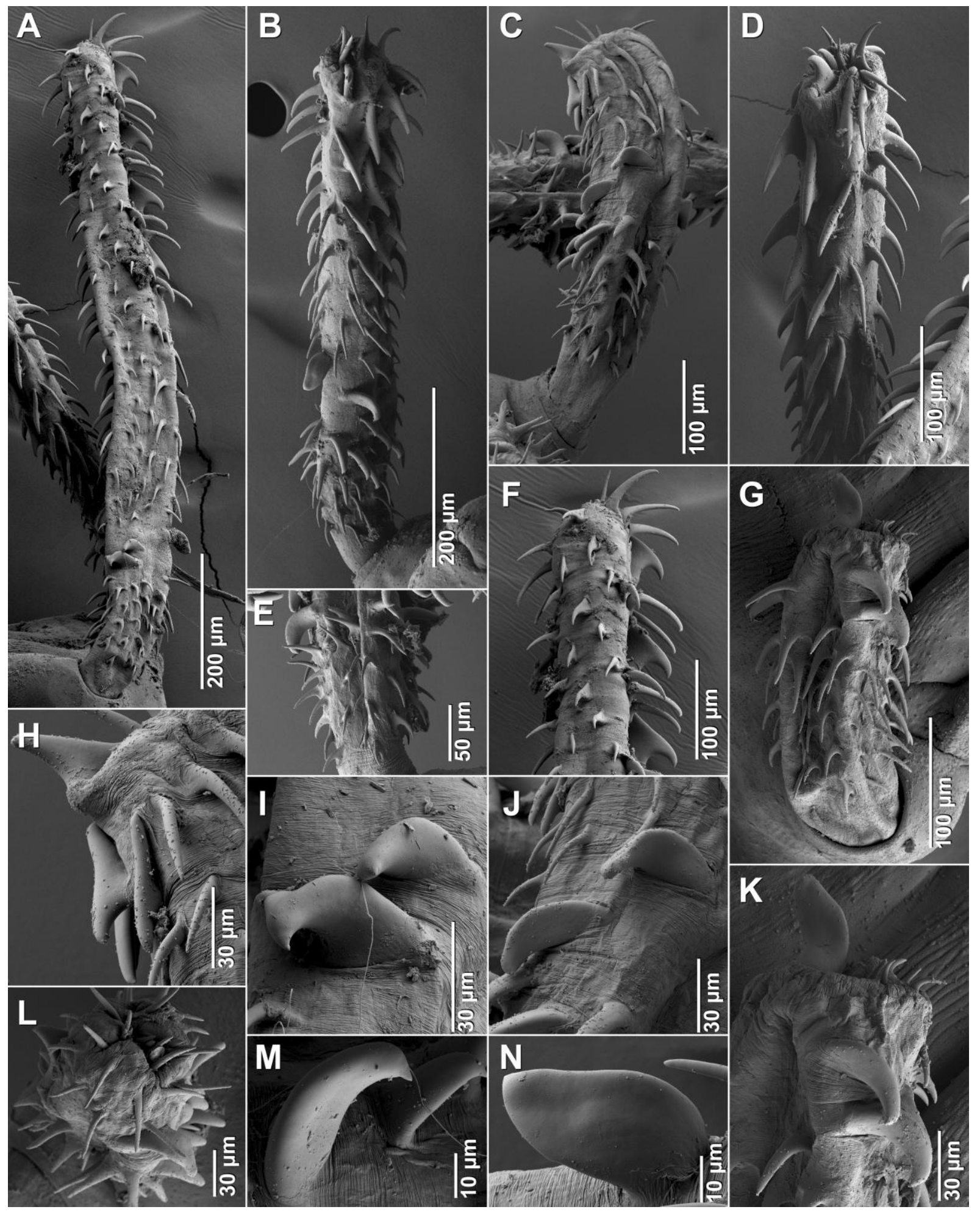




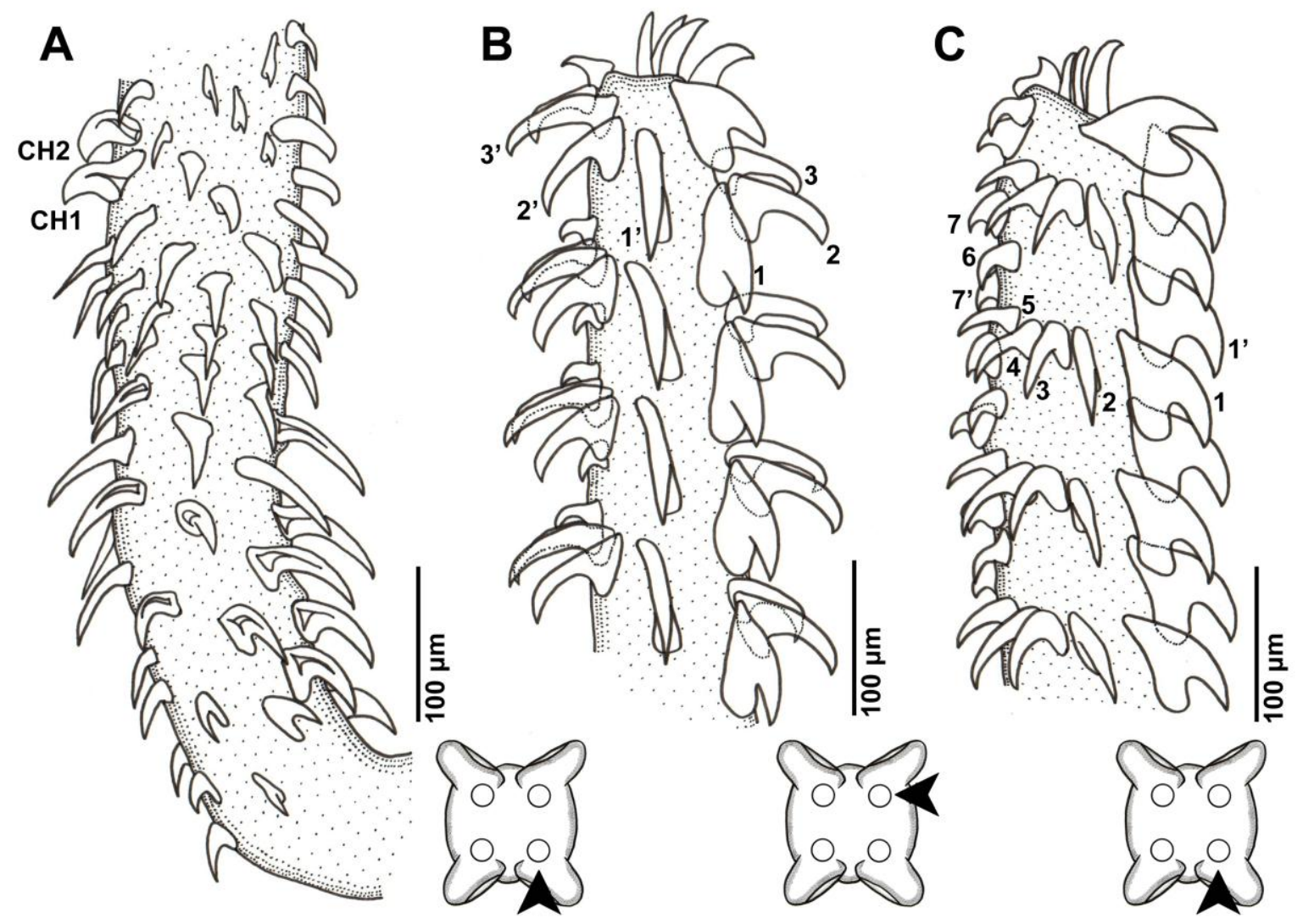

Table 1 Metrical data for most characteristic morphological features of species of Shirleyrhynchus Beveridge \& Campbell, 1988 from different countries

\begin{tabular}{|c|c|c|c|c|c|}
\hline Species & \multicolumn{2}{|c|}{$\begin{array}{l}\text { S. panamensis n. } \\
\text { sp. }\end{array}$} & $\begin{array}{l}S . \\
\text { aetobatidis } \\
\text { (Shipley \& } \\
\text { Hornell, } \\
\text { 1906) }\end{array}$ & \multicolumn{2}{|c|}{$\begin{array}{l}\text { S. butlerae } \\
\text { Beveridge \& } \\
\text { Campbell, } 1988\end{array}$} \\
\hline Country & \multirow{2}{*}{\multicolumn{2}{|c|}{$\begin{array}{l}\text { Panama } \\
\text { Present study }\end{array}$}} & Sri Lanka & \multirow{2}{*}{\multicolumn{2}{|c|}{$\begin{array}{l}\text { Australia } \\
\text { Beveridge \& } \\
\text { Campbell (1988) }\end{array}$}} \\
\hline Source & & & $\begin{array}{l}\text { Present } \\
\text { study }\end{array}$ & & \\
\hline & Range & Mean & Holotype & Range & Mean \\
\hline \multicolumn{6}{|c|}{$\begin{array}{l}\text { Measureme } \\
\text { nts }\end{array}$} \\
\hline SL & $\begin{array}{l}3,890- \\
4,055\end{array}$ & 3,989 & $6,300^{\mathrm{a}}$ & $\begin{array}{l}4,370- \\
5,200\end{array}$ & 4,740 \\
\hline PBO & $360-500$ & 450 & $960^{\mathrm{b}}$ & $450-630$ & 520 \\
\hline PVA & $\begin{array}{l}1,730- \\
1,930\end{array}$ & 1,830 & $3,780^{\mathrm{b}}$ & $\begin{array}{l}2,420- \\
3,050\end{array}$ & 2,750 \\
\hline PBU & $\begin{array}{l}1,960- \\
2,180\end{array}$ & 2,081 & $2,300^{\mathrm{b}}$ & $\begin{array}{l}1,620- \\
2,030\end{array}$ & 1,830 \\
\hline PBUW & $445-515$ & 478 & $1,060^{\mathrm{b}}$ & $550-1,000$ & 690 \\
\hline PPBU & $0-230$ & 78 & $220^{\mathrm{b}}$ & $110-270$ & 200 \\
\hline $\mathrm{BL}$ & $\begin{array}{l}1,920- \\
2,220\end{array}$ & 2,075 & $2,300^{\mathrm{b}}$ & $\begin{array}{l}1,620- \\
2,030\end{array}$ & 1,830 \\
\hline
\end{tabular}




\begin{tabular}{llllll} 
BW & $185-245$ & 211 & $480^{\mathrm{b}}$ & $120-230$ & 180 \\
TWS & $90-110$ & 102 & $125^{\mathrm{a}}$ & $80-110$ & 90 \\
TWM & $90-95$ & 93 & $105^{\mathrm{a}}$ & $30-50$ & 40 \\
Ratios & & & & & \\
PVA:PBO & $3.5-5.2$ & 4.1 & $4.5^{\mathrm{c}}$ & 4.24 & \\
PBU:PBO & $4.1-6.0$ & 4.7 & $3.1^{\mathrm{c}}$ & 3.94 & \\
\hline
\end{tabular}

${ }^{\mathrm{a}}$ Observation of the holotype (present study); ${ }^{\mathrm{b}}$ After Beveridge \& Campbell (1998); ${ }^{\mathrm{c}}$ Calculated from the line-drawing of Beveridge \& Campbell (1998) (figure 1)

Table 2 Hook measurements for Shirleyrhynchus aetobatidis (Shipley \& Hornell, 1906) and S. butlerae Beveridge \& Campbell, 1988

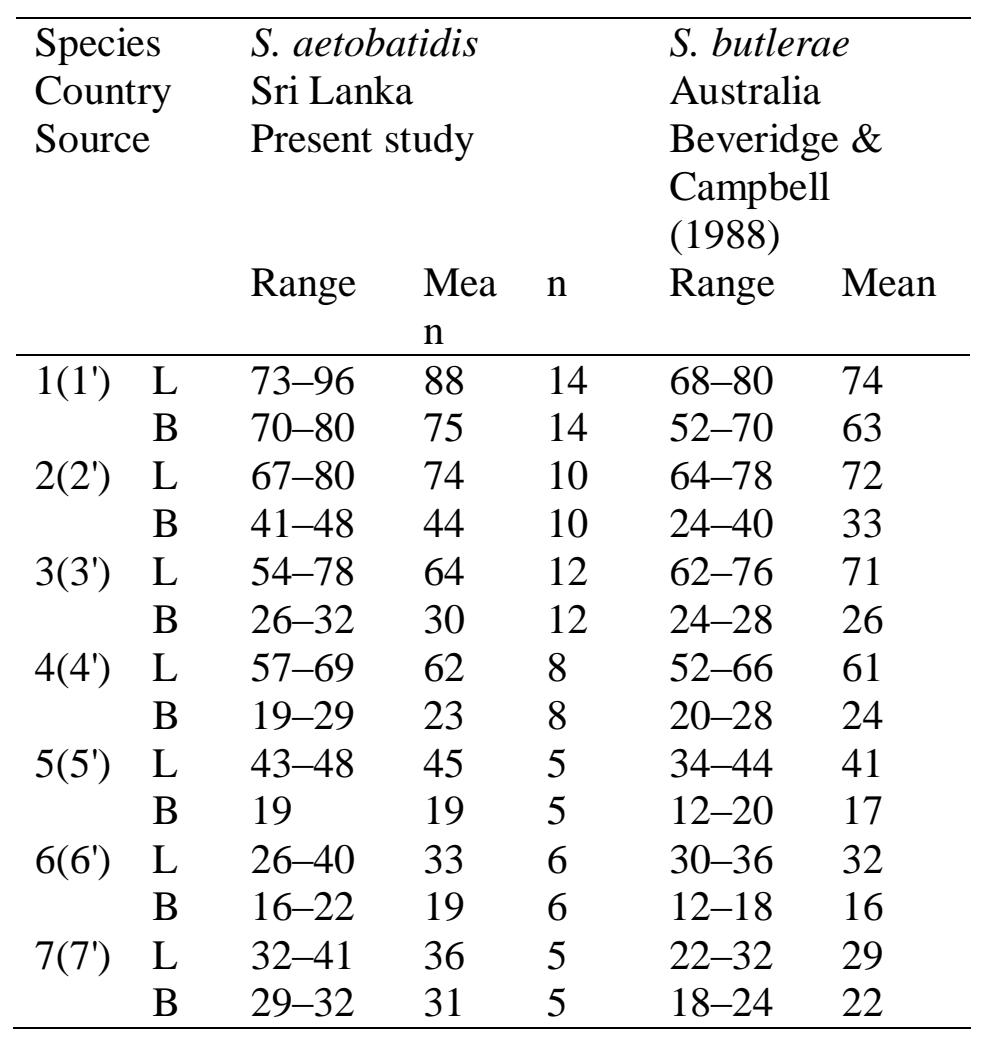




\section{University Library}

\section{- M I N E R VA}

\section{A gateway to Melbourne's research publications}

Minerva Access is the Institutional Repository of The University of Melbourne

Author/s:

Schaeffner, BC

Title:

Review of the genus Shirleyrhynchus Beveridge \& Campbell, 1988 (Trypanorhyncha:

Shirleyrhynchidae), with the resurrection of S. butlerae Beveridge \& Campbell, 1988 and the description of S. panamensis $\mathrm{n}$. sp.

Date:

2016-06

Citation:

Schaeffner, B. C. (2016). Review of the genus Shirleyrhynchus Beveridge \& Campbell, 1988 (Trypanorhyncha: Shirleyrhynchidae), with the resurrection of S. butlerae Beveridge \& Campbell, 1988 and the description of S. panamensis n. sp.. Syst Parasitol, 93 (5), pp.413-430. https://doi.org/10.1007/s11230-016-9641-0.

Persistent Link:

http://hdl.handle.net/11343/282745 